\title{
Vitamin A and Retinoic Acid Act Synergistically to Increase Lung Retinyl Esters During Normoxia and Reduce Hyperoxic Lung Injury in Newborn Mice
}

\author{
MASHEIKA L. JAMES, A. CATHARINE ROSS, ARLENE BULGER, JOSEPH B. PHILIPS, III, \\ AND NAMASIVAYAM AMBALAVANAN
}

\begin{abstract}
Departments of Pathology [M.L.J., N.A.], Pediatrics [A.B., J.B.P., N.A.], and Cell Biology [N.A.], University of Alabama at Birmingham, Birmingham, Alabama 35233; Department of Nutritional Sciences and Huck Institute for Life Sciences [A.C.R.], The Pennsylvania State

University, University Park, Pennsylvania 16802
\end{abstract}

\begin{abstract}
We have shown that vitamin A (VA) and retinoic acid (RA) synergistically increase lung retinyl ester content in neonatal rats. To confirm whether this biochemical synergism attenuates early neonatal hyperoxic lung injury in mice, we exposed newborn C57BL/6 mice to $95 \% \mathrm{O}_{2}$ or air from birth to $4 \mathrm{~d}$. The agent [vehicle, VA, RA, or the combination vitamin A + retinoic acid (VARA)] was given orally daily. Lung and liver retinyl ester content was measured, and lung injury and development were evaluated. We observed that lung, but not liver, retinyl ester levels were increased more by VARA than by VA or RA alone. Hyperoxic lung injury was reduced by VA and RA, and more so by VARA. VARA attenuated the hyperoxiainduced increases in macrophage inflammatory protein (MIP)-2 mRNA and protein expression, but did not alter hyperoxia-induced effects on peptide growth factors (PDGF, VEGF, and TGF- $\beta 1$ ). The 4-d exposure to hyperoxia or retinoids did not lead to observable differences in lung development. We conclude that the VARA combination has synergistic effects on lung retinyl ester concentrations and on the attenuation of hyperoxia-induced lung injury in newborn mice, possibly by modulation of inflammatory mediators. (Pediatr Res 67: 591-597, 2010)
\end{abstract}

$\mathrm{V}$ ery premature infants are at high risk for bronchopulmonary dysplasia (BPD) (1). Vitamin A (VA; retinol) deficiency often observed in premature infants is associated with a higher incidence of BPD (2). Randomized controlled trials and a recent systematic review indicate VA supplementation decreases BPD and/or death $(3,4)$. Despite supplementation, $25 \%$ of infants remain VA deficient (4). The persistence of biochemical VA deficiency may be due to impaired VA transport as transthyretin, a major VA transport protein, is reduced by inflammation (5).

Retinoids are important for normal lung development and maturation (6,7). Hyperoxia induces lung injury, and may contribute to BPD (1). Animal models have shown that administration of retinoic acid (RA, the principal metabolite of VA) attenuates hyperoxic lung injury $(8,9)$. We have shown that a combination of VA (the nutrient) and RA (the metab-

Received September 29, 2009; accepted February 6, 2010.

Correspondence: Namasivayam Ambalavanan, M.D., 525 New Hillman Building619 South 20th Street, University of Alabama at Birmingham, Birmingham, AL 35249; e-mail: ambal@uab.edu

Supported by NIH R01 CA-90214 (A.C.R.), R01 HL092906 (N.A.), K08 HD-046513 (N.A.), CCRI (N.A.), Dorothy Foehr Huck funds (A.C.R.), Southern Regional Education Board (M.L.J.), and UAB Gaston Fellowship (M.L.J.). olite) improved tissue retinoid stores much more than either VA or RA alone in infant rats $(10,11)$. It is possible that the functional consequence of this increase in tissue retinoid stores is a synergism in the attenuation of hyperoxic lung injury, which may be of therapeutic relevance in premature neonates as the administration of RA may circumvent the effects of a reduction in VA transport.

The objective of this study was to determine whether the combination of VA and RA in the newborn mouse model would increase lung retinyl ester content and reduce early hyperoxic lung injury to a greater extent compared with VA or RA administered alone.

\section{METHODS}

Experimental animals and animal care. The study was approved by the Institutional Animal Care and Use Committee (IACUC) and was consistent with the Public Health Service policy on Humane Care and Use of Laboratory Animals (Office of Laboratory Animal Welfare, 2002).

Neonatal mouse model of hyperoxic lung injury (in vivo). Newborn C57BL/6 mice along with their dam were exposed to hyperoxia $\left(95 \% \mathrm{O}_{2}\right)$ or room air from birth to $4 \mathrm{~d}$ of age in a Plexiglas chamber. The $\mathrm{O}_{2}$ concentration (OM-100 oxygen analyzer, Newport Medical Instruments, Newport Beach, CA), humidity, temperature, and barometric pressure (Fisherbrand Digital Barometer, Fisher Scientific, Pittsburgh, PA) within the chamber were continuously monitored.

Experimental design. Newborn mouse pups when exposed to either air or hyperoxia were given one of four agents: vehicle (canola oil), VA, RA, or vitamin A + retinoic acid (VARA) daily for $4 \mathrm{~d}$, and then killed. At least four litters were used for each of these eight groups. Two litters in each group were used for evaluation of lung injury, and the other two litters were used for evaluation of lung and liver retinyl ester content. Additional litters (Airvehicle, Air-VARA, Hyperoxia-vehicle, and Hyperoxia-VARA groups) were used either for bronchoalveolar lavage fluid (BALF) collection or for calculation of the wet to dry weight ratio.

Administration of vehicle, VA, RA, or VARA. VA (all-trans-retinyl palmitate, Sigma Chemical Co.-Aldrich, St. Louis, MO) was diluted directly in canola oil to a concentration of $0.1 \mathrm{mmol} / \mathrm{g}$ oil $(2 \times$ concentrate). For RA (all-trans-RA, Sigma Chemical Co.-Aldrich), $200 \mu \mathrm{L}$ ethanol was added to 3 $\mathrm{mg} \mathrm{RA}$, and $800 \mu \mathrm{L}$ oil was then added to achieve a concentration of 0.01 $\mathrm{mmol} / \mathrm{g}(2 \times$ concentrate $)$. The $2 \times$ concentrates of VA and RA were mixed 1:1 (wt:wt) with oil to form the $1 \times$ doses for administration, or 1:1 with each other to form the VARA dose (0.05 mmol VA: 0.005 mmol RA per $\mathrm{g}$ dose).

Abbreviations: BALF, bronchoalveolar lavage fluid; BPD, bronchopulmonary dysplasia; MIP, macrophage inflammatory protein; MCP, onocyte chemoattractant protein; RA, retinoic acid; RANTES, regulated upon Activation, normal T-cell expressed, and secreted; RE, retinyl esters; VA, vitamin A; VARA, vitamin A + retinoic acid 
Table 1. Scoring system for lung injury and macrophage abundance

\begin{tabular}{|c|c|}
\hline \multicolumn{2}{|c|}{ Epithelial injury } \\
\hline 0 & Normal intact epithelium \\
\hline 1 & Rare cells have separated from epithelium \\
\hline 2 & $\begin{array}{l}10-25 \% \text { of epithelial cells have separated from } \\
\text { underlying basement membrane }\end{array}$ \\
\hline 3 & $25-50 \%$ of epithelium has separated \\
\hline 4 & $51-75 \%$ of epithelium has separated \\
\hline 5 & $>75 \%$ of epithelial cells have separated \\
\hline \multicolumn{2}{|c|}{ Hemorrhage } \\
\hline 0 & No red blood cells (RBC) outside of blood vessels \\
\hline 1 & Few interstitial RBC \\
\hline 2 & Few RBC in some alveoli \\
\hline 3 & Moderate number of RBC in some alveoli \\
\hline 4 & Many RBC in most alveoli \\
\hline 5 & Large numbers of RBC in all alveoli \\
\hline \multicolumn{2}{|c|}{$\begin{array}{l}\text { Macrophage } \\
\text { abundance }\end{array}$} \\
\hline 0 & None-rare \\
\hline 1 & $1-10 \%$ of alveoli/saccules contain macrophages \\
\hline 2 & $10-25 \%$ \\
\hline 3 & $25-75 \%$ \\
\hline 4 & $>75 \%$ \\
\hline
\end{tabular}

Retinoids were stored at $4^{\circ} \mathrm{C}$ in foil-wrapped vials. The doses were administered into the mouse pup's mouth at $2 \mu \mathrm{L}$ per day daily for $4 \mathrm{~d}$. These doses were based on our previous studies in rat pups (10). The dose selected was 20,000 IU (6 mg retinol)/kg for VA (100 IU for a 5-g mouse pup), based on Humphrey et al. (12) who provided 50,000 IU to $2.5 \mathrm{~kg}$ neonates. For RA, the dose was $500 \mu \mathrm{g} / \mathrm{kg}$ with an assumed $80 \%$ absorption (3.1 $\mu \mathrm{g}$ for a $5 \mathrm{~g}$ pup), on the basis of the work of Massaro and Massaro (13).

Evaluation of lung and liver retinol levels. Lung and liver retinol and retinyl esters (RE) were measured by HPLC (10).

Evaluation of lung injury. Lung injury was evaluated in at least six animals per group from two litters. Lungs were fixed in inflation $\left(25 \mathrm{~cm} \mathrm{H}_{2} \mathrm{O}\right.$ pressure) using $10 \%$ formalin. Ten random high power $(400 \times)$ fields from 5 $\mu \mathrm{m} H \& E$ stained sections of a midcoronal section from apex to base of both lungs were evaluated, using a scoring system by an observer masked to treatment group (Table 1). Lung sections were stained with Pan Macrophage Marker F4/80 (Abcam, Cambridge, MA) and Myeloperoxidase (Thermo Scientific, Fremont, CA) for evaluation of macrophages and neutrophils, respectively. Primary antibodies were used at 1:100 dilutions for $30 \mathrm{~min}$ followed by appropriate secondary antibodies conjugated with AlexaFluor 594 (Invitrogen, Eugene, OR). Slides were then evaluated for macrophage and neutrophil abundance using a scoring system (Table 1) by an observer masked to slide identity. Quantitative morphometric analysis was carried out by light microscopy interfaced with an image analysis system (MetaMorph 6.2v4 software, Universal Imaging Corp., Downingtown, PA).

BALF was collected by tracheostomy and cannulation with a $24 \mathrm{G}$ cannula, and two instillations of $0.3 \mathrm{~mL}$ of sterile PBS. BALF was assayed for total protein using the Bradford Assay (Bio-Rad) and for cytoplasmic lactate dehydrogenase (LDH, a marker of cell injury) (Sigma Chemical Co.-Aldrich).

Quantitative real-time PCR for mRNA was performed as described previously $(14,15)$ on homogenized lungs for cytokines known to be involved in hyperoxic lung injury or with BPD/death: IL-1 $\beta$ (16,17), IL-6 (16-18), TNF- $\alpha$ (17-19), IL-10 (16), Monocyte chemoattractant protein (MCP)-1 $(20,21)$, Macrophage inflammatory protein (MIP)-2 $\alpha(21,22)$, and regulated on activation, normal T-cell expressed, and secreted (RANTES) (16). The mouse primer sequences are listed in Table 2. Protein concentrations of these cytokines were evaluated in whole lung homogenates by ELISA (R\&D Systems, Minneapolis, MN \& SA Biosciences, Frederick, MD), and normalized to total protein measured using the Bradford Assay. To batch process all the samples simultaneously for better validity, only the four main groups $\left(21 \% \mathrm{O}_{2}\right.$ Vehicle, $21 \% \mathrm{O}_{2}$ VARA, 95\% $\mathrm{O}_{2}$ Vehicle, and 95\% $\mathrm{O}_{2}$ VARA) were evaluated.

Quantitative real-time PCR was performed for peptide growth factors known to be involved in hyperoxic lung injury: PDGF $(23)$, VEGF $(24,25)$, and TGF- $\beta 1$ (26). These peptide growth factors were also measured by ELISA (R\&D Systems) in whole lung homogenates.

Evaluation of lung development. Alveolar development was evaluated by mean linear intercept (MLI) (27), radial alveolar counts (RAC) (28), and secondary septal crest density $(15)$ as previously described $(14,15)$.
Table 2. Mouse primer sequences for real time quantitative PCR

\begin{tabular}{ll}
\hline \multicolumn{1}{c}{ Primer name } & \multicolumn{1}{c}{ Sequence } \\
\hline 18S forward & GTC TGC CCT ATC AAC TTT CG \\
18S reverse & ATG TGG TAG CCG TTT CTC A \\
PDGF forward & TAA CAC CAG CAG CGT CAA GTG \\
PDGF reverse & CTG GAC CTC TTT CAA TTT TGG C \\
VEGF forward & GAG CGG AGA AAG CAT TTG TTT G \\
VEGF reverse & CGT TCG TTT AAC TCA AGC TGC C \\
TGF- $\beta 1$ forward & GCC CTG GAT ACC AAC TAT TGC TT \\
TGF- $\beta 1$ reverse & AGT TGG CAT GGT AGC CCT TG \\
IL-1 $\beta$ forward & CCA TCC ACG CTG TTT TGA CC \\
IL-1 $\beta$ reverse & ACC AAG CTT TTT TGC TGT GAG TCC \\
IL-6 forward & TTG CCT TCT TGG GAC TGA TGC T \\
IL-6 reverse & GTA TCT CTC TGA AGG ACT CTG G \\
MIP- $2 \alpha$ forward & CCACTCTCAAGGGGGCAAA \\
MIP- $2 \alpha$ reverse & TACGATCCAGGCTTCCCGGG \\
MCP- 1 forward & AGG TCC CTG TCA TGC TTC TGG \\
MCP- 1 reverse & GTG AAT GAG TAG CAG CAG GTG AG \\
TNF- $\alpha$ forward & AGG ACT CAA ATG GGC TTT C \\
TNF- $\alpha$ reverse & AGG TCT GAA GGT AGG AAG G \\
IL-10 forward & CTG CTC CAC TGC CCT TGC TCT TAT T \\
IL-10 reverse & GTG AAG ACT TTC TTT CAA ACA AAG \\
RANTES forward & TGG CAG GAG TGC AAC AAG AA \\
RANTES reverse & CTC AAG TTC GCT CAG CTT TCC T \\
\hline
\end{tabular}

Statistics. Data are presented as the mean \pm SEM. Lung and liver retinyl ester contents, lung developmental indices, and lung injury scores were analyzed by a three-way ANOVA (Factors: Oxygen, VA, RA), followed by multiple comparison testing by the Holm-Sidak method if significant differences (at $p<0.05$ ) were noted by the ANOVA. When the variance terms were unequal among groups, $\log _{10}$ transformation was performed before statistical testing.

\section{RESULTS}

The mouse pups exposed to hyperoxia did not have obvious respiratory distress or impaired survival. Administration of retinoids was well tolerated. No differences in growth were noted with hyperoxia or with retinoid administration at $4 \mathrm{~d}$.

Lung retinyl ester concentration. Seventy mouse pups were evaluated for lung RE (6-15/group). In air-exposed animals, VA and RA both increased lung RE content to a comparable extent, whereas the combination of VA and RA led to a marked synergistic increase in lung RE content, as the increase by VARA was more than the increase by the same amount of VA or RA alone (Fig. 1A). Hyperoxia-exposed animals given vehicle had lower lung RE content, whereas VA and VARA both led to significant and comparable increases in lung RE content. The synergistic effect of the VARA combination on lung RE content that was seen in air-exposed animals was attenuated in hyperoxia. RA alone did not significantly increase lung RE in hyperoxia (Fig. 1A). The relative proportions of lung REs were similar for all treatment groups, showing a major peak of retinyl palmitate with a shoulder of retinyl oleate, followed by a second peak of retinyl stearate (data not shown).

Liver retinyl ester concentration. Fifty-three mouse pups were evaluated for liver RE (4-7/group). In both air-exposed animals and hyperoxia-exposed animals, VA and VARA moderately increased liver RE content (Fig. 1B). RA did not change liver RE in air-exposed animals, although a small but statistically significant decrease was noted in the hyperoxic mice (Fig. 1B). 
Histology. Sixty-three mouse pups were evaluated by histology (6-13/group). In air-exposed animals, VA, RA, and VARA did not change lung injury scores (Table 3). Hyperoxia increased lung injury scores in vehicle-exposed mice, although the magnitude of injury was mild (average score per field $<2$ ) (Table 3; Fig. 2). In the hyperoxia-exposed animals, administration of VA, RA, and VARA lowered injury scores compared with the vehicle group, and there was a further decrease in injury scores in the VARA group compared with the RA group (Table 3; Fig. 2). There was no significant increase in alveolar macrophages in the hyperoxia-exposed mice (Table 3). Very few neutrophils were observed on the myeloperoxidase staining, indicating a lack of neutrophilic infiltrate at this time point. No differences in wet-to-dry weight ratio or lung volumes were noted among the groups (data not shown).

A
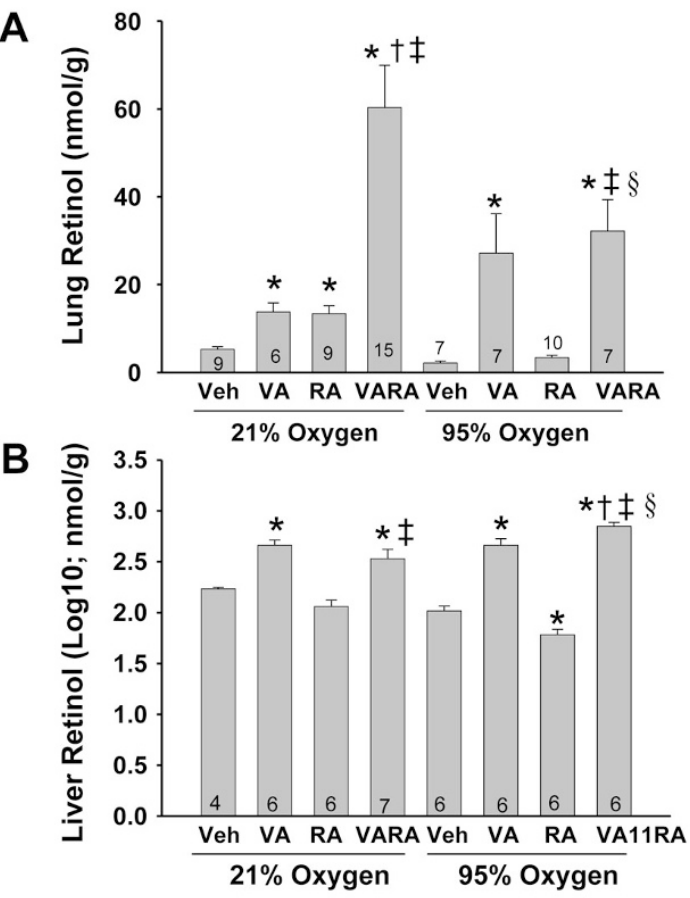

Figure 1. Lung and liver retinyl ester concentrations in neonatal mice exposed to room air or hyperoxia, while being treated with vehicle, VA alone, RA alone, or VARA. Lung and liver RE (nmol/g) were analyzed on day 4. Panel $A$, lung retinyl ester concentrations. [mean \pm SEM; $n$ per group shown at base of bar]. Panel $B$, liver retinyl ester concentrations. [mean \pm SEM of $\log _{10}$ transformed data; $n$ per group shown at base of bar] $\left({ }^{*} p<0.05 v s\right.$ corresponding vehicle, $\pitchfork p<0.05$ vs corresponding VA, $\ddagger p<0.05$ vs corresponding RA, $\$ p<0.05$ vs corresponding air).
Cytokines. Hyperoxia increased mRNA of IL-1 $\beta$, IL-6, MCP-1, MIP- $2 \alpha$, and TNF- $\alpha$, and decreased that of IL-10 (Fig. 3). VARA supplementation prevented the hyperoxiainduced increases of IL- $1 \beta$, IL- 6 , and TNF- $\alpha$ but did not affect the MCP-1 increase. The hyperoxia-induced reduction in IL-10 was prevented by VARA. VARA supplementation at $21 \% \mathrm{O}_{2}$ did not change gene expression of any of the evaluated cytokines. RANTES gene expression did not change with either hyperoxia or VARA.

Changes in protein concentration of these cytokines in the lung homogenates however did not follow the changes in mRNA, with the exception of MIP- $2 \alpha$, which was increased in the hyperoxia-vehicle group and was similar to air vehicle and air VARA in the hyperoxia-VARA group (Fig. 3). IL-1 $\beta$ and RANTES protein were not significantly changed with either

A

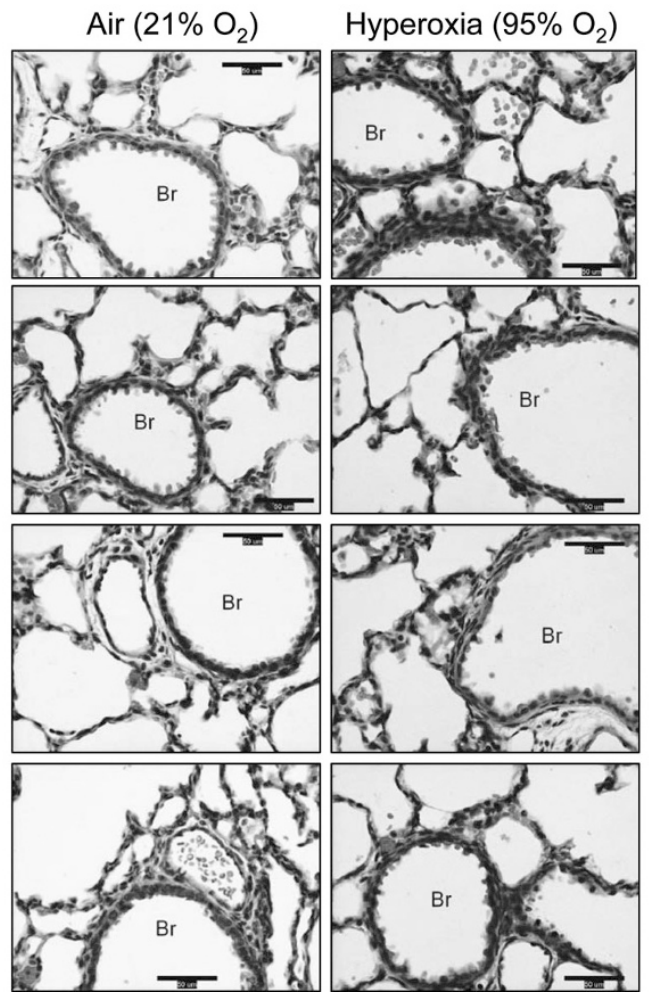

Figure 2. Photomicrographs of lungs from neonatal mice exposed to room air or hyperoxia while being treated with $A$, vehicle; $B$, VA alone; $C$, RA alone; or $D$, VARA. (H\&E stain; $400 \times$; calibration bar $=50 \mu \mathrm{m} ; \mathrm{Br}=$ Bronchus). Exposure to hyperoxia led to hemorrhage (erythrocytes within alveoli and in alveolar septae) and airway epithelial injury (denuded epithelial cells within Br) that were attenuated with VA, RA, and to a greater extent with VARA.

Table 3. Lung injury and macrophage abundance scores

\begin{tabular}{|c|c|c|c|c|c|c|c|c|}
\hline & \multicolumn{4}{|c|}{$21 \% \mathrm{O}_{2}(n=6 / \mathrm{gp})$} & \multicolumn{4}{|c|}{$95 \% \mathrm{O}_{2}(n=6 / \mathrm{gp})$} \\
\hline & Vehicle & VA & RA & VARA & Vehicle & VA & RA & VARA \\
\hline Airway epithelial injury & $0.35 \pm 0.1$ & $0.32 \pm 0.15$ & $0.32 \pm 0.17$ & $0.27 \pm 0.14$ & $2.3 \pm 0.43 \S$ & $1.2 \pm 0.6^{*} \S$ & $1.7 \pm 0.5 \S$ & $0.5 \pm 0.1 * \dagger \ddagger \S$ \\
\hline Hemorrhage & $0.17 \pm 0.1$ & $0.25 \pm 0.14$ & $0.22 \pm 0.2$ & $0.22 \pm 0.1$ & $2.2 \pm 0.4 \S$ & $1.25 \pm 0.6^{*} \S$ & $1.7 \pm 0.3 * \S$ & $0.83 \pm 0.1 * \leftarrow \S$ \\
\hline Macrophage index & $2.16 \pm 0.4$ & $2.0 \pm 0.0$ & $1.33 \pm 0.5$ & $2.00 \pm 0.0$ & $2.80 \pm 0.4$ & $2.75 \pm 0.5$ & $2.0 \pm 0.8$ & $2.16 \pm 1.2$ \\
\hline
\end{tabular}

Group mean values ( \pm SEM).

$* p<0.05$ compared with corresponding vehicle.

$\dagger p<0.05$ compared with corresponding VA.

$\neq p<0.05$ compared with corresponding RA.

$\S p<0.05$ compared with corresponding air $\left(21 \% \mathrm{O}_{2}\right)$. 

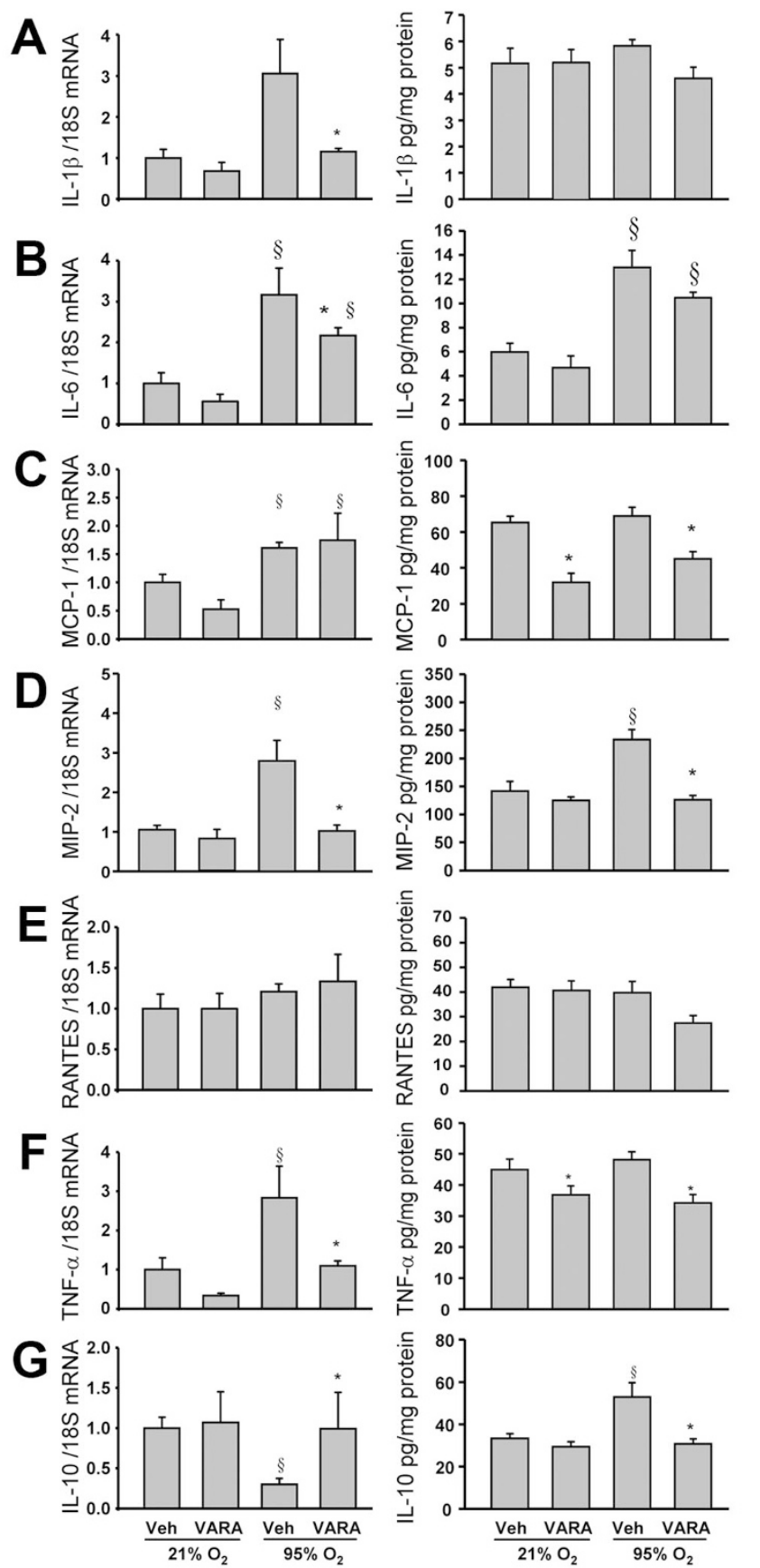

Figure 3. Cytokine gene expression and protein levels in lungs of neonatal mice treated with vehicle (veh) or VARA while exposed to room air or hyperoxia. Gene expression and protein levels of $(A)$ IL-1 $\beta$, (B) IL-6, $(C)$ MCP-1, $(D)$ MIP-2, (E) RANTES, $(F)$ TNF- $\alpha$, and $(G)$ IL-10 in lung homogenates were analyzed on day 4 by competitive real-time PCR and by ELISA, respectively (Mean \pm SEM, $n=6$ animals per group; $* p<0.05 v s$ corresponding vehicle, $\$ p<0.05 v s$ corresponding air).

hyperoxia or VARA. IL-6 increased with hyperoxia, and VARA did not change IL-6 significantly in either air or hyperoxia compared with vehicle at the same oxygen concentration. Hyperoxia did not alter MCP-1 and TNF- $\alpha$, and VARA reduced MCP-1 and TNF- $\alpha$ in both air and hyperoxia conditions compared with vehicle. IL-10 protein was increased in the hyperoxia-vehicle group, and this increase was prevented by VARA.
Peptide growth factors. Neither hyperoxia nor VARA supplementation significantly changed PDGF mRNA or protein in lung homogenates (Fig. 4). VEGF mRNA was increased only in the hyperoxia-VARA group, but VEGF protein was increased in both hyperoxia-vehicle groups and hyperoxiaVARA groups (Fig. 4). A trend toward increased TGF- $\beta 1$ mRNA expression was noted in hyperoxia-vehicle and hyperoxia-VARA groups $\left(0.05<p<0.20\right.$ for effect of $\left.95 \% \mathrm{O}_{2}\right)$, but total (latent + active) TGF- $\beta 1$ protein was similar in all groups, and active TGF- $\beta 1$ protein was reduced in the hyperoxia-vehicle and hyperoxia-VARA groups (Fig. 4).

BALF analysis. LDH was increased in the BALF of the hyperoxia-vehicle group $\left(\mathrm{A}_{490-670}: 0.027 \pm 0.006\right.$ [mean + $\mathrm{SEM}], p<0.05$ versus other groups), while LDH concentrations were similar in the air-vehicle $(0.016 \pm 0.002)$, airVARA $(0.013 \pm 0.002)$, and hyperoxia-VARA $(0.013 \pm$ 0.002) groups. Protein concentrations were not significantly different (mean + SEM in $\mu \mathrm{g} / \mathrm{mL}$, air-vehicle: $6.4 \pm 1$; air-VARA: $7.2 \pm 1$; hyperoxia-vehicle: $11.8 \pm 4$; hyperoxiaVARA: $7.2 \pm 4 ; p=0.2$ by 2-way ANOVA).

Lung development. Changes in MLI and secondary crest density over this brief time period were not statistically significant $(p>0.05)$ (Table 4). RAC was lower in pups exposed to hyperoxia, but administration of VA, RA, and VARA did not change RAC significantly (Table 4).

\section{DISCUSSION}

We observed that an equimolar combination of VA and RA increased lung retinyl ester concentration in a newborn mouse model more than either VA or RA alone, confirming our previous studies in neonatal rats that the VARA combination synergistically increases lung RE content (10). A novel observation was that the synergistic effect of VARA on lung RE content seen in air-exposed newborn mice was blunted in hyperoxia-exposed mice, suggesting increased consumption or decreased uptake of lung RE during hyperoxia. In addition, VARA demonstrated synergism in attenuating early hyperoxic lung injury, accompanied by prevention of hyperoxia-induced increases in MIP-2 mRNA and protein. VARA also prevented hyperoxia-induced increases in gene expression of several pro-inflammatory cytokines (IL-1 $\beta$, IL-6, and TNF- $\alpha$ ) and hyperoxia-induced reduction of IL-10, with less consistent changes in protein concentrations of these cytokines.

Lung development in the human from week 24 of gestation through the first $2 \mathrm{y}$ of age parallels lung development of mice in the first two postnatal weeks $(29,30)$, and the newborn mouse lung is therefore a good model for lung injury in preterm infants. Exposure of neonatal mice to hyperoxia during this period of rapid lung development leads to pathophysiology similar to human BPD with decreased alveolarization (31). Retinoids are essential for normal lung morphogenesis and postnatal maturation (32). Veness-Meehan et al. (9) demonstrated that RA treatment of newborn rats during hyperoxia improves survival and alveolarization. The exact mechanisms by which retinoids attenuate hyperoxia effects in the newborn lung are not certain, but modulation of cytochrome P4501A enzymes (8), growth factor expression 

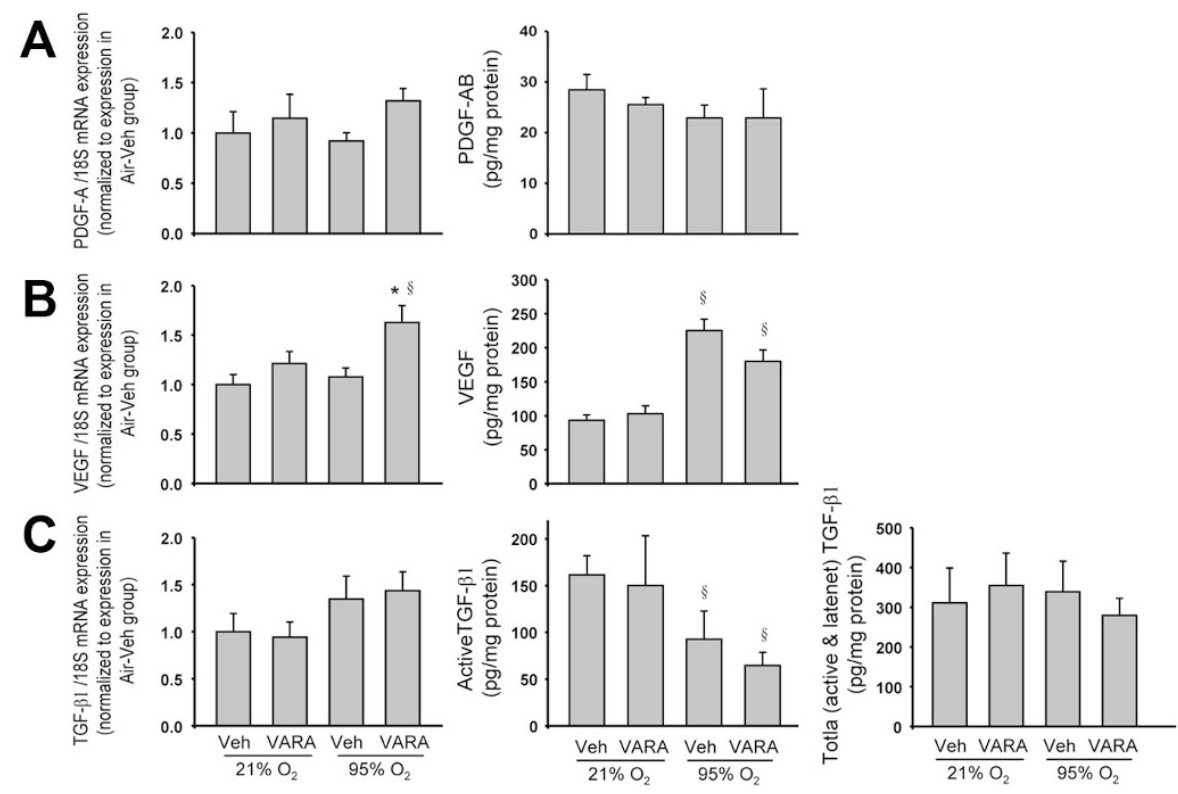

Figure 4. Peptide growth factor gene expression and protein concentration in lungs of neonatal mice treated with vehicle (veh) or VARA when exposed to room air or hyperoxia. Gene expression and protein concentrations of $(A)$ PDGF, (B) VEGF, and (C) TGF- $\beta 1$ in lung homogenates were analyzed on day 4 by competitive real-time PCR and by ELISA, respectively. (Mean \pm SEM, $n=6$ animals per group; $* p<0.05$ vs corresponding vehicle, $\S p<0.05$ vs corresponding air).

Table 4. Lung development assessment

\begin{tabular}{|c|c|c|c|c|c|c|c|c|}
\hline & \multicolumn{4}{|c|}{$21 \% \mathrm{O}_{2}(n=6 / \mathrm{gp})$} & \multicolumn{4}{|c|}{$95 \% \mathrm{O}_{2}(n=6 / \mathrm{gp})$} \\
\hline & Vehicle & VA & RA & VARA & Vehicle & VA & RA & VARA \\
\hline $\operatorname{MLI}(\mu \mathrm{m})$ & $60.9 \pm 7$ & $57.8 \pm 3$ & $58.7 \pm 9$ & $62.4 \pm 11$ & $66.6 \pm 3$ & $63.0 \pm 8$ & $72.5 \pm 9$ & $58.2 \pm 2$ \\
\hline RAC (septae) & $10.1 \pm 4$ & $9.3 \pm 1.3$ & $7.9 \pm 0.4$ & $9.4 \pm 1.0$ & $5.8 \pm 3$ & $7.2 \pm 0.7$ & $7.7 \pm 1.8$ & $7.9 \pm 1.7$ \\
\hline $\mathrm{SSC}\left(\right.$ per $\left.50,000 \mu \mathrm{m}^{2}\right)$ & $4.4 \pm 0.3$ & $4.9 \pm 0.3$ & $4.7 \pm 0.3$ & $4.8 \pm 0.3$ & $4.3 \pm 0.3$ & $4.4 \pm 0.3$ & $4.2 \pm 0.3$ & $4.7 \pm 0.3$ \\
\hline
\end{tabular}

SSC, secondary septal crests.

MLI, RAC, and SSC showed no statistically significant differences between groups, except for a reduction in RAC in the $95 \% \mathrm{O}_{2}$-vehicle group compared with the $21 \% \mathrm{O}_{2}$-vehicle group.

(33,34), or CRABP-I (35) may play a role. Regardless of the mechanism by which retinoids exert their effect, an increase in lung RE content is essential for this benefit. Neonates have very low VA reserves due to the limited transplacental VA passage (36), and lung RE content declines abruptly before birth (37). As RA administration increases alveolar septation even in normally nourished rodents (13), physiologically low levels of RE at birth may be marginal and rate limiting for lung development. We have previously shown that the VARA combination is several-fold more effective in increasing lung RE content than either VA or RA separately $(10,11)$. The present study determined that this increase in lung RE content may be of functional significance.

The hyperoxia-induced increases in pro-inflammatory cytokines and reduction in the anti-inflammatory IL-10 mRNA, and the attenuation of these changes with VARA indicates a possible mechanism of action of retinoids. However, except for MIP- $2 \alpha$, we observed that changes in protein concentrations of these cytokines did not correlate with mRNA changes. It is possible that post-transcriptional changes in protein synthesis or stability maybe involved and possibly regulated by retinoids. An alternative explanation is that techniques for measuring mRNA and protein differ in sensitivity. We have observed similar discordance between mRNA and protein estimations of various cytokines at later time points $(7 \mathrm{~d}$ and $14 \mathrm{~d}$ ) in the hyperoxic newborn mouse model (unpublished data). These results emphasize the importance of measurement of not just gene expression but also corresponding protein concentrations, as well as the complexity of inflammatory regulation in this model. MIP- $2 \alpha$, the murine equivalent of IL-8 in humans, is a potent neutrophil and macrophage chemoattractant, and blockade of its receptor CXCR2 reduces hyperoxic lung injury in adult animals (38). It is possible that retinoid-induced attenuation of hyperoxic increases in MIP-2 mRNA and protein contribute to its mechanism of action by a reduction in subsequent lung inflammatory cell infiltrate.

We noted that hyperoxia increased VEGF protein and decreased active TGF- $\beta 1$ in lung homogenates. Increased VEGF has been noted by other investigators from days 4 to 9 followed by a decrease from days 12 to 14 (25), indicating that temporal profiles of these mediators may be important. VEGF protein levels are also initially high followed by a decline in premature infants who subsequently develop BPD/death (24). Studies involving hyperoxia-exposed newborn animal models have demonstrated increased TGF- $\beta$ signaling $(26,39)$, but these studies have not evaluated early time points. We speculate that differences in TGF- $\beta$ signaling may be isoform specific and time dependent in the newborn lung, and the initial reduction in active TGF- $\beta$ may possibly initiate impaired alveolarization, whereas later increased TGF- $\beta$ signaling may contribute to a profibrogenic state.

The demonstration of VARA synergism is of clinical relevance. Increased VA dosing is not sufficient to alleviate VA deficiency in extremely low birth weight infants with lung 
inflammation, due to a lack of transport of VA to the lung (5). This study overcomes this hurdle by coadministration of VA and RA. As RA increased lung RE, and RA is not converted to RE, increased lung RE content must be due to regulation of retinol metabolism or distribution by RA. Although RA regulates retinol metabolism and increases RE content modestly, $\mathrm{VA}$ is rate limiting for the storage of larger amounts of RE in the lungs (10). In the VARA preparation, the molar ratio of RA to VA is 1 to 10 , suggesting that a small relative amount of RA influences the distribution of a larger amount of VA. The synergistic effect of the VARA combination on lung RE content indicates that VA and RA have different but interacting roles in lung RE storage (10). Similar to our previous results in newborn rats, liver RE content increased only modestly and only to the VA component of VARA, possibly due to rapid oxidation of RA in the liver (40). The synergistic effect of VARA on lung RE was blunted with hyperoxic exposure, possibly due to increased RE consumption or decreased uptake, although this hypothesis was not specifically investigated in this study.

However, there are limitations to this study. First, although hyperoxia-exposed newborn mice are a common reproducible animal model, this model may not simulate all aspects of human BPD. Effects of VA and RA in newborn mice may not be very similar to their effects in preterm infants. As our study was designed to evaluate the effects of short-term hyperoxia on lung retinyl esters and early lung injury, we did not observe effects on lung development and noted only mild lung injury and few inflammatory cells. Studies in newborn rats have shown that lung myeloperoxidase is not increased until day 6 of hyperoxia (22), and newborn mice exposed to $80 \%$ oxygen for $8 \mathrm{~d}$ did not have neutrophil infiltration (41). The rationale for evaluation at the early 4-day time point, even though lung injury is not severe, was to identify the early hyperoxiainduced changes that sets into motion subsequent inflammation/injury. Once lung inflammation is established, it is difficult to determine the sequence and relevance of mediators as many cytokines and growth factors are released by inflammatory cells. Despite these limitations, this study has many strengths, including the analysis of not only biochemical evidence of RE storage but also the functional impact on lung injury in a clinically relevant model.

In conclusion, this study demonstrates the efficacy of a combination of VA and RA in increasing not only lung RE concentrations but also in reducing hyperoxic lung injury in a newborn mouse model. The combination of VA and RA has the therapeutic potential of reducing BPD to a greater extent than with VA supplementation alone. Further investigation is required to determine whether the synergism of VARA combination attenuates other models of lung injury and whether this synergism is limited to the neonatal period.

\section{REFERENCES}

1. Ambalavanan N, Carlo WA 2004 Bronchopulmonary dysplasia: new insights. Clin Perinatol 31:613-628

2. Shenai JP, Chytil F, Stahlman MT 1985 Vitamin A status of neonates with bronchopulmonary dysplasia. Pediatr Res 19:185-188

3. Darlow BA, Graham PJ 2007 Vitamin A supplementation to prevent mortality and short and long-term morbidity in very low birthweight infants. Cochrane Database Syst Rev 4:CD000501
4. Tyson JE, Wright LL, Oh W, Kennedy KA, Mele L, Ehrenkranz RA, Stoll BJ, Lemons JA, Stevenson DK, Bauer CR, Korones SB, Fanaroff AA 1999 Vitamin A supplementation for extremely-low-birth-weight infants. N Engl J Med 340:19621968

5. Ambalavanan N, Ross AC, Carlo WA 2005 Retinol-binding protein, transthyretin, and C-reactive protein in extremely low birth weight (ELBW) infants. J Perinatol 25:714-719

6. Chailley-Heu B, Chelly N, Lelievre-Pegorier M, Barlier-Mur AM, Merlet-Benichou C, Bourbon JR 1999 Mild vitamin A deficiency delays fetal lung maturation in the rat. Am J Respir Cell Mol Biol 21:89-96

7. Massaro D, Massaro GD 2003 Retinoids, alveolus formation, and alveolar deficiency: clinical implications. Am J Respir Cell Mol Biol 28:271-274

8. Couroucli XI, Liang YW, Jiang W, Barrios R, Moorthy B 2006 Attenuation of oxygen-induced abnormal lung maturation in rats by retinoic acid: possible role of cytochrome P4501A enzymes. J Pharmacol Exp Ther 317:946-954

9. Veness-Meehan KA, Pierce RA, Moats-Staats BM, Stiles AD 2002 Retinoic acid attenuates O2-induced inhibition of lung septation. Am J Physiol Lung Cell Mol Physiol 283:L971-L980

10. Ross AC, Ambalavanan N, Zolfaghari R, Li NQ 2006 Vitamin A combined with retinoic acid increases retinol uptake and lung retinyl ester formation in a synergistic manner in neonatal rats. J Lipid Res 47:1844-1851

11. Ross AC, Li NQ, Wu L 2006 The components of VARA, a nutrient-metabolite of vitamin A and retinoic acid, act efficiently together and separately to increase retinyl esters in the lungs of neonatal rats. J Nutr 136:2803-2807

12. Humphrey JH, Agoestina T, Wu L, Usman A, Nurachim M, Subardja D, Hidayat S, Tielsch J, West KP Jr, Sommer A 1996 Impact of neonatal vitamin A supplementation on infant morbidity and mortality. J Pediatr 128:489-496

13. Massaro GD, Massaro D 1996 Postnatal treatment with retinoic acid increases the number of pulmonary alveoli in rats. Am J Physiol 270:L305-L310

14. Ambalavanan N, Nicola T, Hagood J, Bulger A, Serra R, Murphy-Ullrich J, Oparil S, Chen YF 2008 Transforming growth factor-beta signaling mediates hypoxia-induced pulmonary arterial remodeling and inhibition of alveolar development in newborn mouse lung. Am J Physiol Lung Cell Mol Physiol 295:L86-L95

15. Nicola T, Hagood JS, James ML, Macewen MW, Williams TA, Hewitt MM, Schwiebert LM, Bulger A, Oparil S, Chen YF, Ambalavanan N 2009 Loss of Thy-1 inhibits alveolar development in the newborn mouse lung. Am J Physiol Lung Cell Mol Physiol 296:L738-L750

16. Ambalavanan N, Carlo WA, D’Angio CT, McDonald SA, Das A, Schendel D, Thorsen P, Higgins RD; Eunice Kennedy Shriver National Institute of Child Health and Human Development Neonatal Research Network 2009 Cytokines associated with bronchopulmonary dysplasia or death in extremely low birth weight infants. Pediatrics 123:1132-1141

17. Johnston CJ, Wright TW, Reed CK, Finkelstein JN 1997 Comparison of adult and newborn pulmonary cytokine mRNA expression after hyperoxia. Exp Lung Res 23:537-552

18. Ben-Ari J, Makhoul IR, Dorio RJ, Buckley S, Warburton D, Walker SM 2000 Cytokine response during hyperoxia: sequential production of pulmonary tumor necrosis factor and interleukin-6 in neonatal rats. Isr Med Assoc J 2:365-369

19. Guthmann F, Wissel H, Schachtrup C, Tölle A, Rüdiger M, Spener F, Rüstow B 2005 Inhibition of TNFalpha in vivo prevents hyperoxia-mediated activation of caspase 3 in type II cells. Respir Res 6:10

20. Cooper JA Jr, Fuller JM, McMinn KM, Culbreth RR 1998 Modulation of monocyte chemotactic protein-1 production by hyperoxia: importance of RNA stability in control of cytokine production. Am J Respir Cell Mol Biol 18:521-525

21. D’Angio CT, Johnston CJ, Wright TW, Reed CK, Finkelstein JN 1998 Chemokine mRNA alterations in newborn and adult mouse lung during acute hyperoxia. Exp Lung Res 24:685-702

22. Deng H, Mason SN, Auten RL Jr 2000 Lung inflammation in hyperoxia can be prevented by antichemokine treatment in newborn rats. Am J Respir Crit Care Med 162:2316-2323

23. Buch S, Han RN, Cabacungan J, Wang J, Yuan S, Belcastro R, Deimling J, Jankov R, Luo X, Lye SJ, Post M, Tanswell AK 2000 Changes in expression of plateletderived growth factor and its receptors in the lungs of newborn rats exposed to air or $60 \% \mathrm{O}(2)$. Pediatr Res 48:423-433

24. Bhandari V, Choo-Wing R, Lee CG, Yusuf K, Nedrelow JH, Ambalavanan N, Malkus H, Homer RJ, Elias JA 2008 Developmental regulation of NO-mediated VEGF-induced effects in the lung. Am J Respir Cell Mol Biol 39:420-430

25. Hosford GE, Olson DM 2003 Effects of hyperoxia on VEGF, its receptors, and HIF- $2 \alpha$ in the newborn rat lung. Am J Physiol Lung Cell Mol Physiol 285:L1611168

26. Alejandre-Alcázar MA, Kwapiszewska G, Reiss I, Amarie OV, Marsh LM, SevillaPérez J, Wygrecka M, Eul B, Köbrich S, Hesse M, Schermuly RT, Seeger W, Eickelberg O, Morty RE 2007 Hyperoxia modulates TGF-beta/BMP signaling in a mouse model of bronchopulmonary dysplasia. Am J Physiol Lung Cell Mol Physiol 292:L537-L549

27. McGowan S, Jackson SK, Jenkins-Moore M, Dai HH, Chambon P, Snyder JM 2000 Mice bearing deletions of retinoic acid receptors demonstrate reduced lung elastin and alveolar numbers. Am J Respir Cell Mol Biol 23:162-167

28. Cooney TP, Thurlbeck WM 1982 The radial alveolar count method of Emery and Mithal: a reappraisal 1; postnatal lung growth. Thorax 37:572-579

29. Burri P 1997 Structural aspects of prenatal and postnatal development and growth for the lung. In: McDonald JA (ed) Lung Growth and Development. Dekker, New York, p 1-35

30. Thurlbeck WM 1975 Postnatal growth and development of the lung. Am Rev Respir Dis 111:803-844 
31. Warner BB, Stuart LA, Papes RA, Wispe JR 1998 Functional and pathological effects of prolonged hyperoxia in neonatal mice. Am J Physiol 275:L110-L117

32. Maden M, Hind M 2004 Retinoic acid in alveolar development, maintenance and regeneration. Philos Trans R Soc Lond B Biol Sci 359:799-808

33. Chetty A, Nielsen HC 2002 Regulation of cell proliferation by insulin-like growth factor 1 in hyperoxia-exposed neonatal rat lung. Mol Genet Metab 75:265-275

34. Matsuura O, Kadomatsu K, Takei Y, Uchimura K, Mimura S, Watanabe K, Muramatsu T 2002 Midkine expression is associated with postnatal development of the lungs. Cell Struct Funct 27:109-115

35. Bry K, Lappalainen U 2006 Pathogenesis of bronchopulmonary dysplasia: the role of interleukin 1beta in the regulation of inflammation-mediated pulmonary retinoic acid pathways in transgenic mice. Semin Perinatol 30:121-128

36. Ross AC 2005 Introduction to vitamin A: a nutritional and life cycle perspective. In: Packer L, Obermuller-Jevic U, Kraemer K, Sies H (eds) Carotenoids and Retinoids. Molecular Aspects and Health Issues. American Oil Chemists' Society Press, Champaign, IL, p 23-24
37. Shenai JP, Chytil F 1990 Effect of maternal vitamin-A administration on fetal lung vitamin-A stores in the perinatal rat. Biol Neonate 58:318-325

38. Sue RD, Belperio JA, Burdick MD, Murray LA, Xue YY, Dy MC, Kwon JJ, Keane MP, Strieter RM 2004 CXCR2 is critical to hyperoxia-induced lung injury. J Immunol 172:3860-3868

39. Nakanishi H, Sugiura T, Streisand JB, Lonning SM, Roberts JD Jr 2007 TGF-beta-neutralizing antibodies improve pulmonary alveologenesis and vasculogenesis in the injured newborn lung. Am J Physiol Lung Cell Mol Physiol 293:L151-L161

40. Napoli JL, Posch KP, Fiorella PD, Boerman MH 1991 Physiological occurrence, biosynthesis and metabolism of retinoic acid: evidence for roles of cellular retinol-binding protein $(\mathrm{CRBP})$ and cellular retinoic acid-binding protein (CRABP) in the pathway of retinoic acid homeostasis. Biomed Pharmacother 45:131-143

41. Crouse DT, Cassell GH, Waites KB, Foster JM, Cassady G 1990 Hyperoxia potentiates Ureaplasma urealyticum pneumonia in newborn mice. Infect Immun 58:3487-3493 